補綴誌, J Jpn Prosthodont Soc, 40:448〜453, 1996.

\title{
原著論文
}

\section{老人病院入院患者の口腔状態とデンチャープラークの 細菌構成について}

\author{
一第 1 報 予備調査結果一
}

\begin{tabular}{|c|c|c|c|}
\hline 稔也 & 市川 & 哲雄 & 川本 苗子 \\
\hline 蚋 政信 & 弘田 & 克彦* & 三宅洋一郎* \\
\hline
\end{tabular}

\section{Oral Condition and Microflora of Denture Plaque of Geriatric Inpatients -Part 1 Preliminary Survey-}

Toshiya Kashiwabara, Tetsuo Ichikawa, Naeko Kawamoto, Hideo Kanitani, Masanobu Horiuchi, Katsuhiko Hirota*, Yoichiro Miyake* and Naoyuki Matsumoto

\begin{abstract}
Dental treatment must meet the needs of the rapidly increasing elderly people in Japan. In addition, geriatric inpatients also increased with the increase of elderly people. Investigation was carried out to determine the oral condition and microflora in denture plaque of elderly patients in two geriatric hospitals and Tokushima Dental Hospital. The difference between healthy patients and geriatric inpatients was .discussed. The results of the preliminary survey were as follows:

1. Inpatients in a geriatric hospital were more elderly, and the frequency of edentulous patients was fairly high. The prognosis of the denture was poor because of high frequencies of low residual ridge and oral diskinesia.

2. Denture plaque of geriatric inpatients had the following characteristics compared to that of healthy elderly patients.

1) Numbers of total bacteria, Streptococci, Candida, and Staphylococci in isolated denture plaque of the geriatric inpatients were larger than those of healthy patients.

2) Linear relationships between numbers of total bacteria and Streptococci and between numbers of Candida and Staphylococci were found.

3) The frequency of MRSA in the geriatric inpatients was higher than in the healthy patients.

4) Numbers of total bacteria and Streptococci in denture plaque obtained in the inpatients with heart disease and cerebrovascular accident were much larger than those in the inpatients without these diseases.
\end{abstract}

Key words : elderly patient, edentulous, geriatric, denture plaque, MRSA

徳島大学歯学部歯科補緅学第一講座（主任：松本直之教授）

*徳島大学歯学部口腔細菌学講座 (主任:三宅洋一郎教授)

Department of Removable Prosthodontics, The University of Tokushima, School of Dentistry (Chief : Prof. Naoyuki Matsumoto)

*Department of Microbiology, The University of Tokushima, School of Dentistry (Chief: Prof. Yoichiro Miyake)

平成 7 年 11 月 30 日受付

\section{I. 緒 言}

急速な高齢化社会を迎えているわが国において，歯科医 療もまたその対応が急務とされている。しかし, 補緅治療 の場合, 介護を要する高齢者と, 快適な老後いわゆる QOL の向上を目指すことのできる健康な高齢者とでは治 
療条件が全く異なるため, 両者を区別してその対応を考え る必要がある．特に老人病院入院中の介護を要する高齢者 の，口腔状態と歯科治療の実態に関する調査は少なく，ま た，それらは残存歯数等の簡単な調査にとどまってい る ${ }^{1 \sim 6)}$. その意味においては, 介護を要する高齢者の口腔 状態の現状と，医療全体からみた場合，われわれ歯科医が 行うべき医療は何かを明確にする必要がある。

本研究は, 上記の目的のための予備調査として, 徳島県 下の 2 つの老人病院とその附属の老人保健施設の入所入院 患者 (以下, これらをあわせて老人病院入院患者と呼ぶ）, および徳島大学歯学部附属病院補綴科を受診した患者のう ち全部床義歯装着者を対象に，口腔状態とデンチャープ ラークの細菌構成の調査を行い, 老人病院の実態について 検討した．また，最近，院内感染で問題となっているメチ シリン耐性黄色ブドウ球菌(MRSA) ${ }^{7,8)}$ のデンチャープ ラークにおける出現頻度についても調査した.

\section{II. 実験方法}

\section{1. 口腔状態の調査}

1) 無歯額の比率

徳島大学歯学部附属病院補緅科（TUと略す）を初診と して受診した最近の成人患者 101 名（平成 7 年 1 月〜 7 月) $と$ を受診

した同病院入院患者と同附属老人保健施設入所者 190 名 (平成 6 年 5 月〜 7 年 7 月) のうち無歯顎者数をカルテをも とに調查した. また, 残根上義歯の場合, 同部を欠損とした.

2）全部床義歯装着者の㴿堤状態，オーラルディスキネ ジアの頻度, 咬合面の状態についての調査

対象は上下全部床義歯装着者とし，

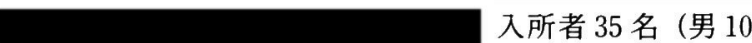

名, 女 25 名, 平均年齢 82 歳）と，その調査と同時期に TUを受診した 50 名（男 12 名，女 38 名，平均年齢 71

歳）である. 評価は 1 人の歯科医の判断によって行われ た．顎堤状態については歯槽頂の高さを基準に“良”，“中 程度”，“悪い”の 3 段階に，オーラルディスキネジアにつ いてはある一定の下顎安静位を維持できるかどうかを基準 に“あり”，“なし”の 2 段階に評価した。 臼歯咬合面の状 態は，市販の咬頭傾斜約 $20^{\circ}$ の人工歯に近いものを“咬頭 あり”, $0^{\circ}$ 人工歯に近いものを“フラット”，その中間の ものの 3 段階に，咬合面の彎曲については下顎義歯の左右 臼歯部の咬合面がほほ平行なものを“フラット”とし，そ れ以外を “モンソン”，および“アンチモンソン”に分け 3 段階に評価した.

\section{2. テンチャープラークの細菌数測定}

の全部床義歯装着者 35 名中 28 名（男 8 名，女 20 名，平均年齢 83 歳）と TU を受診した全部床義歯装着者

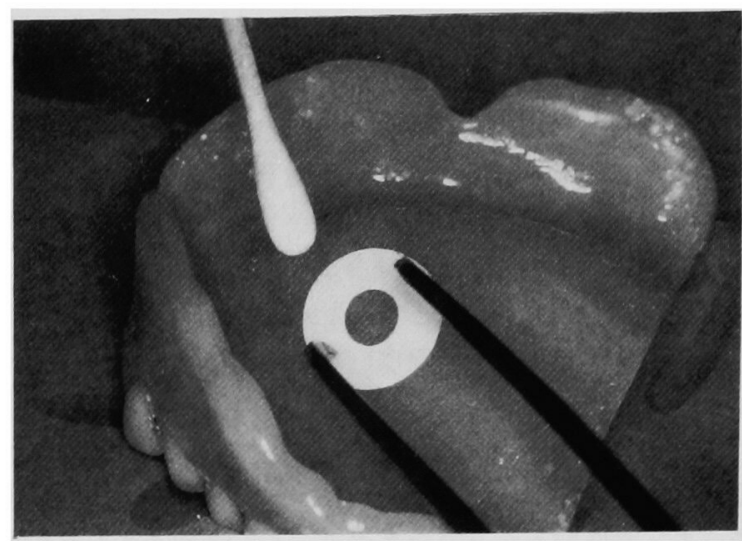

図 1 Isolation of denture plaque デンチャープラークの採取方法

20 名（男 5 名, 女 15 名, 平均年歯 73 歳）からデン チャープラークを図 1 に示すような方法, すなわち，上顎 全部床義歯の口蓋部粘膜面の一定面積 $\left(23.7 \mathrm{~mm}^{2}\right)$ から 綿棒でスクラビング後, 直ちに transfer medium $(0.05 \%$ チオグリコール酸を溶解した $0.1 \mathrm{M}$ phosphate buffered saline）中に覽汼し，その菌液をスパイラルシステム（ス パイラル社）で以下の 4 つの培地に拡散し，培責した。培 養条件は，総細菌数を測定するために BHI 血液寒天培地 で嫌気状態で 48 時間, ブドウ球菌数測定のためにマン ニット食塩培地で $37^{\circ} \mathrm{C}, 48$ 時間, レンサ球菌数測定のた めにミティスサリヴァリウス培地で嫌気状態で 48 時間, カンジダ数測定のためにカンジダ $\mathrm{GE}$ 培地で $37^{\circ} \mathrm{C}, 48$ 時 間培養した．培養後はコロニーをカウントし，採取したデ ンチャープラーク中の総細菌数を求めた。また，MRSA の検出のために黄色ブドウ球菌が同定されたものに対し て, $1 \mathrm{~m} l$ 中 $4 \mu \mathrm{g}$ オキサシリンを含んだ $\mathrm{BHI}$ 寒天培地で 培養を行った（図 2 )。

なお，本システムでの細菌検出限界は総細菌とレンサ球 菌では 1 採取面積当たり 813 個未満, ブドウ球菌とカンジ ダでは 40.7 個未満であり，この場合はゼロとみなした。

\section{III. 結 果}

\section{1. 口腔ならびに義歯の診査}

図 3 は TUで受診した 101 名と】を受診した入院患 者ならびに同老人保健施設に入所中の 190 名についての, 無歯顎者の割合を示す。不明はカルテ上から判断できな かったものである.TUの平均年少は 54 歳, 男女比率は $42 ： 59$ で，そのうち無歯顎者は，上嵿は $19 \%$ ，下顎は $14 \%$ ，上下顎とも無歯顎の割合は $9 \%$ であった。の平 均年齢は 79 歳, 男女比率は $71: 119$ で, そのうち無歯頢

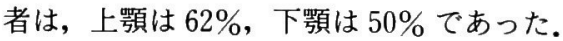

図 4 は TU の 50 名と の 35 名の全部床義歯装着者の 顎堤状態を, 図 5 はオーラルディスキネジアの頻度を示 


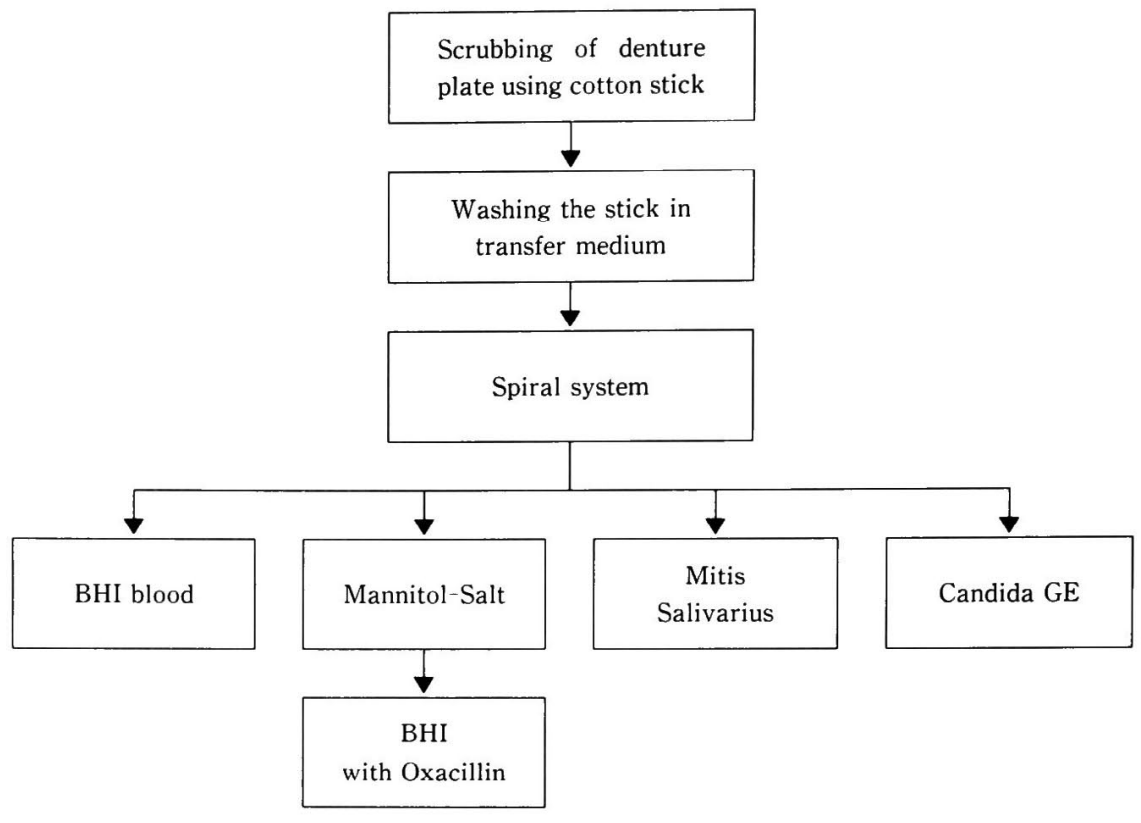

図 2 Identification of bacteria in denture plaque デンチャープラークの培養方法

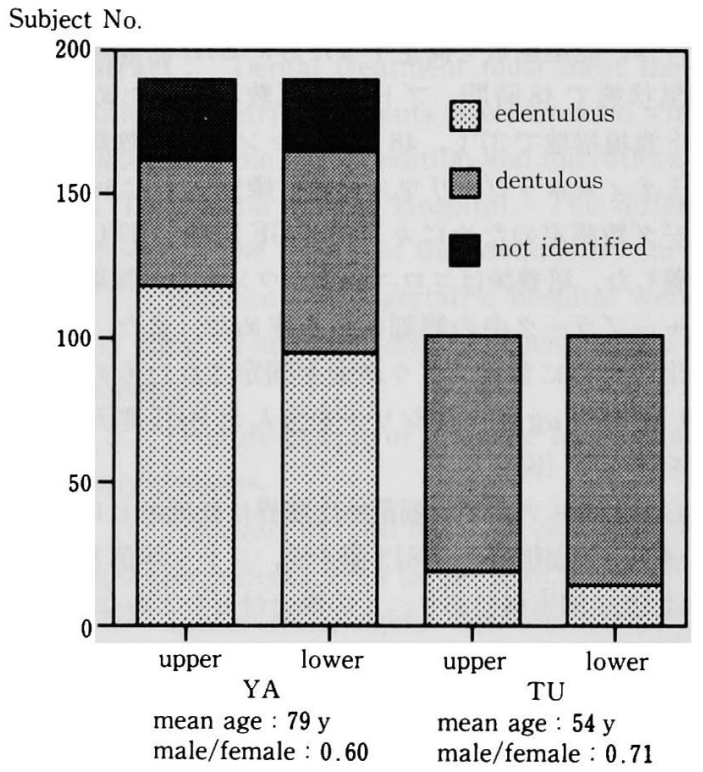

図 3 Frequency of edentulous patients 無菌䫣者の割合

す。顎堤状態は, 上顎では, TUと EL 間には差は認めら れなかったが, 下顎では, ELにおいて顎堤の悪いものが $60 \%$ を越え，TUの $30 \%$ 弱に対して多い傾向が認められ た. 一方, オーラルディスキネジアについては, TUで 4\%であったのに対して ELでは $14 \%$ となり，ELの患者 に多く認められた. 図 6 は ELの咬合面の状態について, 咬頭の高さと彎曲の状態を示したものである，ELにおい ては咬頭歯とフラットの割合, モンソン状と非モンソン状

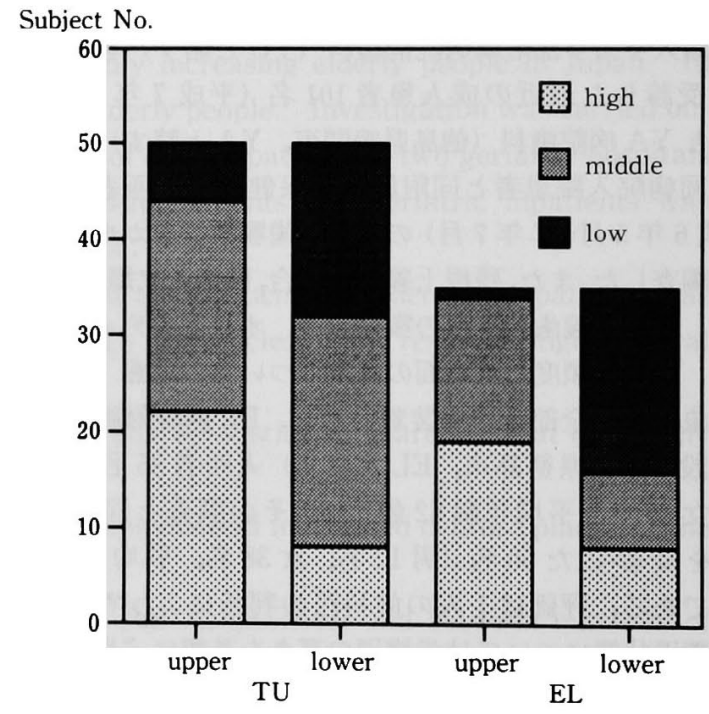

図 4 Condition of alveolar ridge 䫵堤状態

の割合がいずれもほぼ同じであった．一方，TUではすべ て咬頭歯であり，かつ，モンソンカーブであった。

\section{2. デンチャープラークの診査}

表 1 に EL 28 名, TU 20 名から採取されたデンチャー プラークに含まれる 4 種類の細菌数の平均, 検出率, 総細 菌数に対する各細菌数の比率を示す. TUにおいては本方 法で細菌が認められない場合も多いのに対して，ELでデ ンチャープラーク中に含まれる細菌数はきわめて多く, 特 
に病原性のあるブドウ球菌, カンジダの割合が多い傾向が 認められた。

図 7 は MRSA の出現率を示す.すべての患者は現在, 急性の感染症の症状はなく, 抗生物質の投与を受けてはい なかったＥLで採取されたデンチャープラーク 28 例中 ブドウ球菌が分離されたものは 17 例，そのうち 4 例（全 体比率で $14.3 \%$ ）にMRSA が分離された. 一方，TUで

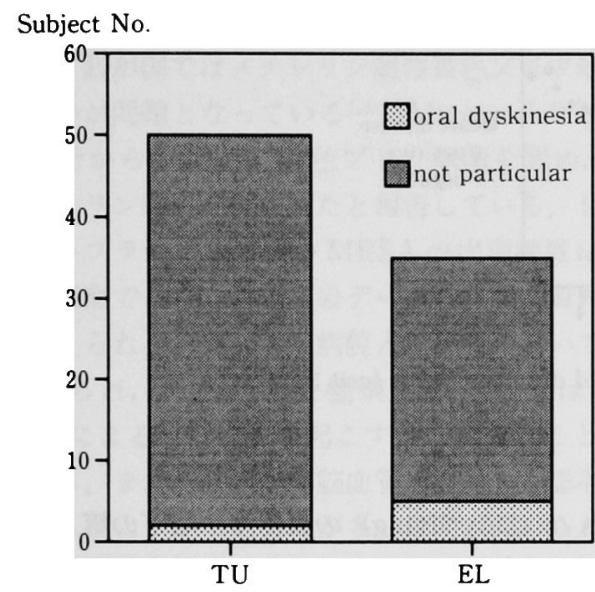

図 5 Frequency of oral dyskinesia オーラルディスキネジアの頻度

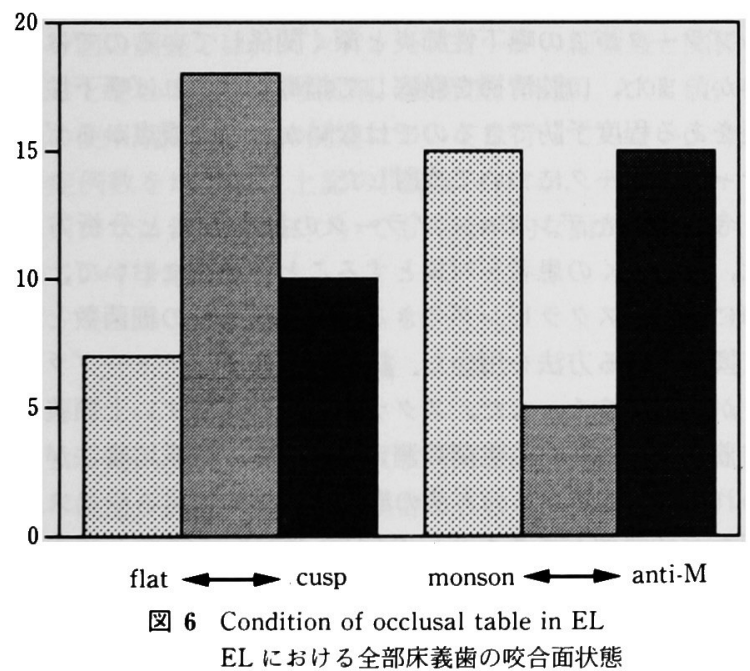

採取されたデンチャープラーク 20 例中ブドウ球菌が分離 されたものは 2 例，そのうち 1 例（全体比率で $5 \%$ ）のみ にMRSA が分離された。

図 8 はELの患者を対象に, 脳血管障害 (cerebrovascular accident）の既往の有無（図上段）と心疾患 (heart disease) の既往の有無（図下段）とに分けて，総 細菌数とレンサ球菌数との関係 (左側), ならびにカンジ ダとブドウ球菌数との関係（右側）を調べたものである. 総細菌数とレンサ球菌数間 $(\mathrm{r}=0.95, \mathrm{p}<0.001)$, ならび にカンジダとブドウ球菌数間 $(r=0.81, \mathrm{p}<0.001)$ には 有意な正の相関が認められた。また，心疾患や脳血管障害 の既往がある場合には, 総細菌数とレンサ球菌数が多い傾 向にあることが認められた.

\section{IV. 考察}

\section{1. 口腔ならびに義歯の診査結果について}

徳島大学歯学部附属病院補経科を受診した無歯顎者の頻 度は $10 \%$ 強であったが，この值は高齢化の進んだ徳島な らびに大学病院補綴科という特殊環境での値であり, 一般 の歯科医院ではその頻度は低いものと想像される。これに 対して老人病院では, 無歯顎者の頻度は $50 \%$ を越えきわ めて高かった。本結果は榎本ら ${ }^{1)}$, 冲本ら ${ }^{21}$, 森ら ${ }^{6 / 2 ゙ の ~}$

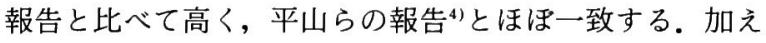
て, 老人病院入院患者の下顎の顎堤条件は大学病院受診者

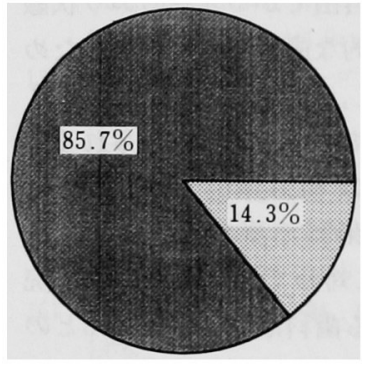

EL

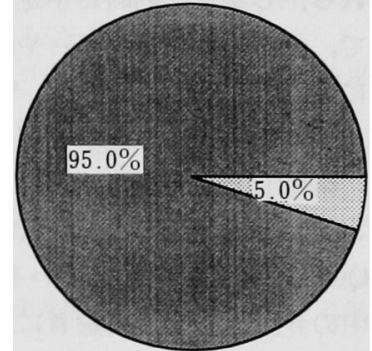

TU
MRSA-detected, 圆 not detected

図 7 Frequency of MRSA MRSA 出現率

表 1 Microflora of denture plaque 採取したデンチャープラークの細菌構成

\begin{tabular}{|c|c|c|c|c|c|c|}
\hline & \multicolumn{3}{|c|}{ EL } & \multicolumn{3}{|c|}{ TU } \\
\hline & $\begin{array}{c}\text { bacteria } \\
\text { number } \\
\left(\text { 個 } / 23.7 \mathrm{~mm}^{2}\right)\end{array}$ & $\begin{array}{l}\text { detected } \\
\text { rate }\end{array}$ & $\begin{array}{l}\text { rate to } \\
\text { total bacteria }\end{array}$ & $\begin{array}{c}\text { bacteria } \\
\text { number } \\
\left(\text { 個 } / 23.7 \mathrm{~mm}^{2}\right)\end{array}$ & $\begin{array}{l}\text { detected } \\
\text { rate }\end{array}$ & $\begin{array}{l}\text { rate to } \\
\text { total bacteria }\end{array}$ \\
\hline Total bacteria & $1.04 \times 10^{6}$ & $100 \%$ & - & $2.03 \times 10^{4}$ & $50 \%$ & - \\
\hline Streptococci & $4.78 \times 10^{5}$ & $100 \%$ & $45.84 \%$ & $9.31 \times 10^{3}$ & $45 \%$ & $45.80 \%$ \\
\hline Candida & $1.53 \times 10^{4}$ & $70.0 \%$ & $1.47 \%$ & $2.03 \times 10^{0}$ & $5 \%$ & $0.01 \%$ \\
\hline Staphylococci & $8.36 \times 10^{3}$ & $58.6 \%$ & $0.80 \%$ & $1.63 \times 10^{1}$ & $10 \%$ & $0.08 \%$ \\
\hline
\end{tabular}



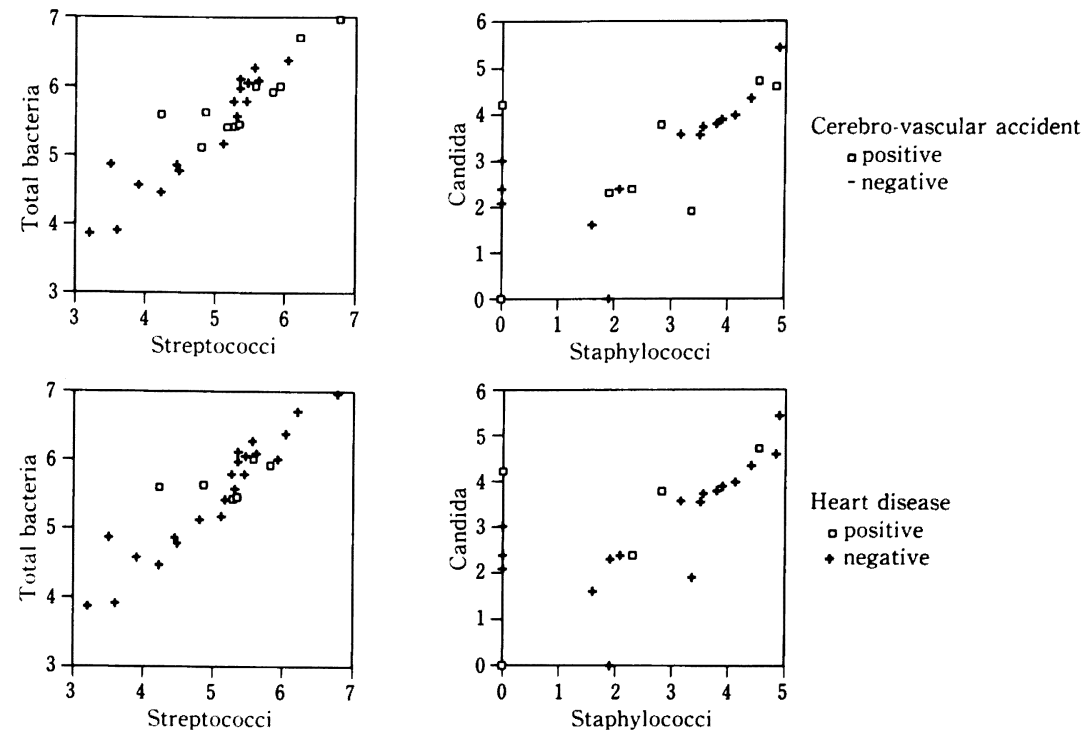

図 8 Relationship between systemic disease and microflora of denture plaque (usit: $10^{\mathrm{n}} \mathrm{cfu}$ ) 全身疾患とデンチャープラークの細菌鋠との関連

のそれよりも悪く,また,オーラルディスキネジアの頻度も 高く, 機能的にも困難な症例, いわゆる難症例が多いこと が推測された，使用中の全部床義歯の咬合面の状態につい ては，通法どおり咬頭歯を調節彎曲をつけて排列したもの が多く見受けられたが，正しく咬合しているか否かは不明 である。これらの原因としては，おのおのの群の調査対象 者の平均年齢が，10 歳以上と大きく異なることが考えら れる.しかし，同時に手足が不自由でかつ入院という状態 で, 予防的な口腔ヶアーや継続的な歯科治療が困難なため に,残根上の義歯に移行しやすく,また, 不適合な義歯によ る顎堤の吸収などを引き起こしやすいものと考えられる.

高齢化社会を迎え ${ }^{9}$, 一方では 8020 運動 ${ }^{10)}$ やンプラ ント治療に代表される高度な歯科治療が推進され ${ }^{111}$, QOL の向上に役立っているのに対して，老人病院に入院 中の介護を要する高齢者に対する歯科治療は，ほとんどの 場合，全部床義歯による補経治療が主流となるが，このよ うな患者に対して通法どおりの全部床義歯製作法で対処で きるのか，それとも特殊な治療法を必要とするのか，今 後，何らかの対策が必要であると考えられる.

\section{2. テンチャープラークについて}

デンチャープラークについては従来より義歯性口内炎や 口臭という，口腔環境の視点から捉えられ指導されてき た ${ }^{12,13)}$ が, 高齢者, 特に老人病院に入院している介護を必 要とする者の場合は，口腔環境だけでなく全身面からある いは精神面からも，十分配慮した指導がなされなければな らない。しかも高齢者は免疫能の低下により日和見感染を 起こしやすく，65 歳以上の高齢者の死亡原因の第 2 位は 肺炎で 15〜17\%であるといわれている ${ }^{14,15)}$.これは $\mathrm{ADL}$ (activities of daily living) の低下や，嬩下の第 2 相，つ まり，気道に食物塊が入らないように呼吸を瞬間的に停止 するという協調動作が乱れやすいことなどから，噯下性肺 炎が死亡原因の大きなウエイトを占めているといわれてい る15).そこで，われわれは，デンチャープラークやデンタ ルプラークがこの嚥下性肺炎と梁く関係しているのではな いか, また，口腔清掃を徹底して指導管理すれば嬩下性肺 炎をある程度予防できるのではないかという観点からデン チャープラークについて検討した。

今回用いたデンチャープラークの採取方法と分析方法 は，今後多くの患者を対象とすることを念頭において，綿 棒によってスクラビングできる単位面積当りの細菌数とし て換算できる方法を用いた。採取部位はデンチャープラー クがつきやすく，また，スクラビングがしやすい上領義歯 口蓋粘膜面とした。生菌数測定法は従来, 混釈培養法が行 われてきたが16)，この方法の場合，作業の煩雑さやコスト 面などで問題があるため，今回は，FDA で開発されたス パイラルプレーティング法を用いた ${ }^{17)}$.

デンチャープラークの細菌叢については種々の報告があ るが18 201, 本研究においては, 全身疾患との関連からプ ラークの総量を示す総細菌数と, 義歯性口内炎や日和見感 染の原因菌とされるカンジダと，通性嫌気性グラム陽性球 菌の口腔常在菌であるレンサ球菌とブドウ球菌の 4 種類の 菌数を測定した. なお，レンサ球菌は生体材料への初期付 着に関係し，また，嚥下性肺炎の原因菌と注目されている ミレリグループなどを含んでいる21).ブドウ球菌は化膿性 疾患および心内膜炎などの原因菌とされている22).

EL と TUを比べた場合, EL の総細菌数, レンサ球菌 数, カンジダ数, ブドウ球菌数ともにきわめて多く，口腔 
清掃状態が悪いことが客観的に示された。また，総細菌数 に占めるレンサ球菌, カンジダ, ブドウ球菌の割合も大き かった. しかし，本方法において老人病院入院患者のデン チャープラーク量を対象としたスクラビング面積および希 釈法であったので, 大学病院に来院するような患者に対し ては検出程度が低すぎるようであった。 また, 総細菌数と レンサ球菌数, カンジダ数とブドウ球菌数との間には正の 相関が認められ, 口腔清掃の不良が全身疾患の誘因になる 可能性が示唆された.

近年, わが国ではメチシリン耐性黄色ブドウ球菌による 院内感染が問題となっている 小児の舌から約 $33 \%$ に黄色ブドウ球菌を認め，その $6 \%$ にメチシリン耐性が存在したと報告している.しかし、デ ンチャープラークにおける MRSA の出現頻度についての 報告は皆無であり, 本研究のデー夕は貴重な資料となるも のと考えられる. 特に老人病院入院患者において高い頻度 で認められ, 宿主の免疫機構が低下すれば必然的に MRSAによる感染を引き起こすようになることが十分考 えられる，また，心疾患や脳血管障害をもつ患者ほど総細 菌数ならびにレンサ球菌数が多い傾向が認められた。これ はこのような患者の ADL が低いために義歯清掃が十分で きないことが第 1 の原因と考えられる. また，これが原因 で睘下性肺炎やその他の全身的な疾病を増悪させる, いわ ゆる悪循環を起こしていることも予想される。

今回の調査では, デンチャープラークの細菌叢と関係の あると思われる, 投与薬剈, 食習慣, 年齢, $\mathrm{ADL}$ 值, 義 歯の使用期間などとの関連については行っていない. 今後 は症例数を増やし, 上記の問題点のほか, デンチャープ ラークコントロールについても免疫学的な面から明らかに していく予定である.

\section{V. 結 論}

1. 老人病院入院患者は大学病院補緅科来院の患者と比 べ年齢層が高く, 無歯顎の割合もきわめて大きかった. 特

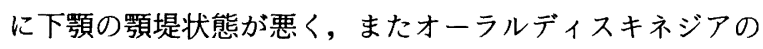
頻度も高く, いわゆる総義歯の難症例のケースが多かっ た。

2. 老人病院入院患者の全部床義歯から採取したデン チャープラークは, 大学病院補綴科来院の全部床義歯装着 者からのものと比べて,

1) 総細菌数, レンサ球菌, カンジダ数, ブドウ球菌と もに多く, また, 総細菌数に占めるレンサ球菌, カンジダ 数, ブドウ球菌の割合も大きかった。

2) 総細菌数とレンサ球菌数, カンジダ数とブドウ球菌 数との間に正の相関が認められた.

3） MRSA の出現頻度が高い傾向にあった.

4）心疾患や脳血管障害をもつ患者ほど総細菌数, レン
サ球菌数の多い傾向が認められた.

\section{文献}

1）榎本友彦，塙 浩昭，島本 聡ほ力，高齢入院患者の口腔内状 況. 歯学 $77: 1752-1758,1990$.

2）冲本公繪, 家入浩二, 松尾浩一ほか。老化と咀哷. 補緅誌 35 ： 931-943, 1991.

3）小川仲子，下山和弘，長尾正囊ほか，老人病院における歯科治 療介護システム作りに関する研究一入院患者の口腔内状況と歯 科治療に対する意識. 老年歯学 $6: 36-41,1992$.

4）平山丈二, 江原俊一，江原健ほか，老人病院における歯科診 療一病院歯科開設より 1 年間一。老年歯学 7:51-55, 1992.

5）鈴木哲也，熊谷 宏，内田達郎ほか。高齢者の咬合支持状況に 関する研究. 補緅誌 $38: 476-484,1993$.

6）森宏樹，関 雅博，田中茂之ほか。老人病院歯科における高 齢者の歯科実態調査. 補経誌 $39: 954-958,1995$.

7) Staat RH, Van Stewart A, Syrwart JF. MRSA : an important consideration for geriatric dentistry practitioners. Spec Care Dentist $11:$ 197-199, 1991.

8) Horiba N, Yoshida T, Suzuki K et al. Isolation of methicillinresistant staphylococci in the dental operatory. J Endod 21 : 21-25, 1995.

9）大森 彌編．新たな高柃化介護システムの構築をめざして，高 踰者介護・自立支援システム研究会資料, 1995.

10）上田裕，新庄文明，田中義広ほか. 高齢者歯科医療マニュア ル 3-59, 京都：永末書店, 1992.

11）関根弘，小宮山彌太郎，重松友寞。 Osseointegrated implant. 歯界展望別冊 デンタルインプラント 87-98, 東京： 医歯薬出版, 1987.

12) Olsen I. Denture stomatitis: Occurrence and distribution of fungi. Acta Odontol Scand 32:329-333, 1974.

13）浜田泰三. デンチャープラークコントロール 1-32, 京都: 永末 書店, 1983.

14）山本俊幸，高齢者の肺炎. 健康長寿に関する国際長寿シンポジ ウム 159-161, 1986.

15）木田厚瑞. 高齢者の呼吸器疾患一䜩下性肺炎の病態について 一. 老年歯学 $10: 11-16,1995$.

16）医科学研究所学友会編. 細菌学実習提要 171-173, 東京: 丸善, 1976.

17）菅原和之，山口恵三，臼井敏明ほか。 スパイラルシステムを用 いた定量培着法の臨床材料への応用. 最新検查 $2: 393-402$, 1984.

18) Gibbons RJ, Socransky SS, de Araujo WC et al. Study of the predominant cultivable microbiota of dental plaque. Arch Oral Biol $9: 365-370,1984$.

19）吉村計宜，尾上孝利，中村長孝ほか、デンチャープラークの細 菌叢. 補経誌 $30: 738-744,1986$.

20）星野悦郎，佐藤ミ千子．全部床義歯付着細菌莎の細菌構成．補 緅誌 $32: 763-766,1988$.

21）新里 敬, 仲宗根勇, 斎藤 厚. Streptococcus milleri group. 臨床検查 $38: 552-556,1994$.

22）吉川君之介編. 医科細菌学 219-222, 東京：南江堂, 1989.

23) Miyake $Y$, Iwai $T$, Sugai $M$ et al. Incident and characterization of Staphylococcus aureus from the tongue of children. J Dent Res 70: 1045-1047, 1991. 